\title{
PENGARUH KINERJA KEUANGAN TERHADAP RETURN SAHAM PADA PERUSAHAAN SUB SEKTOR OTOMOTIF YANG TERDAFTAR DI BURSA EFEK INDONESIA
}

\author{
Yudhia Mulya \\ Dosen Tetap Fakultas Ekonomi Universitas Pakuan \\ Ririn Turisna \\ Mahasiswa Fakultas Ekonomi Universitas Pakuan
}

\begin{abstract}
ABSTRAK
Penelitian ini bertujuan untuk menganalisis pengaruh laporan keuangan, rasio solvabilitas (Long Term Debt to Equity Ratio), rasio profitabilitas (Return On Equity, rasio nilai pasar (Earning Per Share, Price Earning Ratio, dan Price to Book Value) terhadap return saham. Metode analisis yang digunakan adalah statistik inferensial, menggunakan analisis regresi linier berganda, uji asumsi klasik, uji t dan uji $F$ dengan aplikasi SPSS. Koefisien untuk $\mathrm{R}$ square disesuaikan $=0.825$ berarti bahwa $82,5 \%$ dari return saham dijelaskan oleh LTDR, ROE, EPS, PER, dan PBV faktor dan 17,5\% dijelaskan oleh variabel lain. Hasil uji F menunjukkan bahwa secara simultan LTDR, ROE, EPS, PER, dan PBV berpengaruh signifikan terhadap return saham dengan $F$ hitung $31,160 \geq F$ tabel 2,73. Sementara $t$ tes menunjukkan bahwa sebagian LTDER memiliki efek negatif yang signifikan terhadap return saham dengan $t_{\text {hitung }}$ dengan $t_{\text {tabel }} \leq(-7,669 \leq-2,05183)$. Kemudian, variabel ROE tidak berpengaruh signifikan terhadap return saham dengan $\mathrm{t}$ hitung $<\mathrm{t}$ tabel $(-5.510$ $<2,05183)$. Sementara, variabel EPS berpengaruh signifikan positif terhadap return saham dengan $t$ hitung $<\mathrm{t}$ tabel $(5,061 \leq 2,05183)$. Variabel PER tidak berpengaruh terhadap return saham dengan $t_{\text {hitung }}<\mathrm{t}_{\text {tabel }}(-1.372$ $<2,05183)$ dan variabel PBV tidak berpengaruh terhadap return saham dengan $\mathrm{t}$ hitung $<\mathrm{t}$ tabel $(-0,2014$ $<2,05183)$.
\end{abstract}

Keyword: Long Term Debt to Equity Ratio (LTDR), Return on Equity (ROE), Earning Per Share (EPS), Price Earning Ratio (PER), Price Book Value (PBV) dan Return Saham.

\begin{abstract}
This study aimed to analyze the effect of financial statement, solvability ratio (Long Term Debt to Equity Ratio), profitability ratio (Return On Equity, market value ratio (Earning Per Share, Price Earning Ratio, and Price to Book Value) on stock return. The analytical method used is inferential statistics, using multiple linear regression analysis, the classical assumption test, $t$ test and $F$ test with SPSS application. The coefficient for adjusted $R$ square $=0,825$ means that $82,5 \%$ of stock return is explained by y LTDR, ROE, $E P S, P E R$, and PBV factors and 17,5\% is explained by other variabel. Result $F$ test shows that simultaneosly

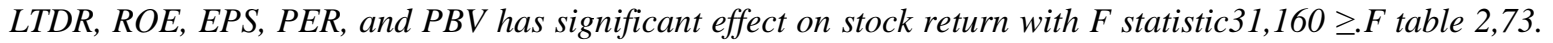
While t test show that partially LTDER has significant negative effect on the stock return with $-t$ statisric $\leq-\mathrm{t}$ table $(-7,669 \leq-2,05183)$. Then, variable ROE has no significant effect on stock return with $t$ statisric $<t$ table $(-5,510<2,05183)$. While, variable EPS has positive significant effect on stock return with $t$ statisric < $t$ table (5,061 $\leq 2,05183)$. Variable PER has no effect to stock return with $t$ statisric $<t$ table ($1,372<2,05183)$ and variable PBV has no effect to stock return with $t$ statisric < t table $(-0,2014<2,05183)$.
\end{abstract}

Keyword: Long Term Debt to Equity Ratio (LTDR), Return on Equity (ROE), Earning Per Share (EPS), Price Earning Ratio (PER), Price Book Value (PBV) dan Return Saham.

JIMFE (Jurnal Ilmiah Manajemen Fakultas Ekonomi)

Volume 2 No. 1 Tahun 2016 Edisi 2, Hal. 41-52 


\section{Pendahuluan}

Pergerakan harga saham emiten sektor otomotif akan sangat dipengaruhi oleh kinerja bisnis perusahaan. Analis First Asia Capital, David N. Sutyanto, mengatakan kenaikan harga bahan bakar minyak pada 18 November lalu memang akan berdampak terhadap fluktuasi harga saham perusahaan di sektor otomotif. Namun, secara keseluruhan, harga saham akan lebih dipengaruhi oleh kinerja bisnis. Menurut David, kondisi itu terlihat dari hasil kinerja saham dua perusahaan grup otomotif nasional, yakni PT Astra International Tbk dengan kode ASII dan PT Indomobil Sukses Internasional Tbk dengan kode IMAS. Kinerja fundamental yang berbeda bisa berdampak pada kinerja saham yang berbeda. Pada Januari-Oktober 2014, penjualan mobil Astra turun 2,8 persen menjadi 526 ribu unit. Berdasarkan kondisi tersebut maka perusahaan-perusahaan melakukan ekspansi agar dapat bersaing. Ekspansi membutuhkan investasi yang cukup besar, dengan demikian perusahaan akan mencari investor atau kreditor untuk memenuhi kebutuhan dana perusahaan dengan cara mengeluarkan surat utang (obligasi), saham biasa atau saham preferen melalui penawaran umum di Bursa Efek Indonesia (BEI) cara tersebut menunjukan hasil yang efektif, hal tersebut terlihat dari banyaknya investor asing dan lokal yang melakukan investasi pada perusahaan sub sektor otomotif. Menurut Ang (1997), ada dua faktor yang mempengaruhi return suatu investasi. Pertama, faktor internal perusahaan seperti kualitas dan reputasi manajemennya, struktur permodalannya, struktur hutang perusahaan, dan sebagainya. Kedua adalah menyangkut factor eksternal, misalnya pengaruh kebijakan moneter dan fiscal, perkembangan sektor industrinya, kondisi ekonomi misalnya terjadinya inflasi, dan sebagainya.

Penelitian mengenai return saham telah beberapa kali dilakukan dengan berbagai variabel independen. Beberapa penelitian dengan menggunakan rasio solvabilitas, rasio profitabilitas, dan rasio nilai pasar terhadap return saham terdapat hasil penelitian yang tidak konsisten. Oleh karena itu, peneliti termotivasi melakukan penelitian ini untuk menguji konsistensi hasil penelitian-penelitian sebelumnya.

Adapun tujuan penelitian ini adalah: 1) Untuk membuktikan bahwa Long Term Debt to Equity Ratio berpengaruh terhadap Return Saham pada perusahaan sub sektor otomotif yang terdaftar di BEI; 2) Untuk membuktikan bahwa Return On Equity berpengaruh terhadap Return Saham pada perusahaan sub sektor otomotif yang terdaftar di BEI; 3) Untuk membuktikan bahwa Earning Per Share berpengaruh terhadap Return Saham pada perusahaan sub sektor otomotif yang terdaftar di BEI; 4) Untuk membuktikan bahwa Price Earning Ratio berpengaruh terhadap Return Saham pada perusahaan sub sektor otomotif yang terdaftar di BEI; 5) Untuk membuktikan bahwa Price to Book Value berpengaruh terhadap Return Saham pada perusahaan sub sektor otomotif yang terdaftar di BEI; dan 6) Untuk menganalisis dan mengukur tingkat pengaruh rasio solvabilitas, rasio profitabilitas, dan rasio nilai pasar terhadap return sahampada perusahaan sub sektor otomotif yang terdaftar di BEI.

\section{Landasan Teori}

Analisis laporan keuangan berguna untuk membantu mangantisipasi kondisi 
masa depan, yang lebih penting lagi adalah sebagai titik awal untuk merencanakan tindakan-tindakan yang akan memperbaiki kinerja di masa depan. Dalam hal ini peneliti menggunakan rasio-rasio keuangan diantaranya yaitu:

\subsection{Rasio Solvabilitas}

According to Brealey, Myers and Allen (2014:762) because debt increases the returns to shareholders in good times and reduce them in bad times, it is said to create financial laverage or solvability. Solvability or Laverage ratios measure how much financial laverage the firm has taken on.

\section{Long Term Debt to Equity Ratio terhadap Return Saham.}

According to Van Horne \& Wachowicz (1998:132) long term debt to equity ratio measure tells us the relative importance of long term debt to the capital structure (long term financing) of the firm. the debt ratios just computed have been based on accounting book value, it is sometimes useful to calculate these ratios using market value. debt ratio tell us the relative proportions of capital contribution by creditors and by owners.

Peneliti sebelumnya yang dilakukan oleh Sonja Yvonne Momuat (2005) menyatakan bahwa LTDR bepengaruh negatif terhadap return saham. Sedangkan menurut Hasrul Siregar dan Fatimah (2013) menyatakan bahwa tidak ada pengaruh LTDR terhadap return saham.

Berdasarkan uraian tersebut, maka dapat dirumuskan hipotesis sebagai berikut.

\section{H1 : Long Term Debt to Equity Ratio (LTDR) berpengaruh negatif terhadap Return Saham}

\subsection{Rasio Profitabilitas}

According to Philippatos \& Sihler (1991, 70) profitability can be measured in three dimensions-sales total asset, and owner's equity and generally can be defined in a number of ways, although for the purposes on hand we will use earnings after taxes (net income).

\section{Return On Equity terhadap Return Saham.}

High ROE reflects the company's efficiency in using its own capital to pruduce high profit for the company itself. This ratio indicates management's succes in maximizing the rate of greater return for the shareholder. The higher the ROE of a company, the better its the performance, so that there will be more ivestors who are interested to invest ther fund in the company, so that the higher the ROE stock return will higher too. (Komala and Nugroho, 2013).

Penelitian yang dilakukan oleh Giovanni Budiman, Desy Arista, Abdul Karim, Okky Safitry, Sinarwati dan Anantawikrama Tungga Atmaja menyimpulkan bahwa ROE perpengaruh positif terhadap return saham. Sedangkan penelitian yang dilakukan oleh Ari Anggraini Winadi Prasetyoning Tyas menyebutkan bahwa ROE berpengaruh negatif terhadap return saham.

Berdasarkan uraian tersebut, maka dapat dirumuskan hipotesis sebagai berikut.

\section{$\mathrm{H}_{2}$ : Return On Equity (ROE) berpengaruh positif terhadap Return Saham}

\subsection{Rasio Nilai Pasar}

Menurut Brigham dan Houston (2006:110) rasio nilai pasar (market value ratio), akan menghubungkan harga saham perusahaan pada laba, arus kas, dan nilai 
buku per sahamnya. Rasio-rasio ini dapat memberikan indikasi kepada manajemen mengenai apa yang dipikirkan oleh para investor tentang kinerja masa lalu dan prospek perusahaan di masa mendatang. Jika rasio-rasio likuiditas, manajemen aktiva, manajemen utang, dan profitabilitas semuanya terlihat baik, maka rasio-rasio nilai pasarnya juga akan tinggi, dan harga saham kemungkinan juga akan tinggi sesuai harapan.

a) Earning Per Share terhadap Return Saham.

According to Pandey (2008:88) The Earnings Per Share is calculated by dividing the profit after taxes by the total number of common shares outstanding. Menurut Widoatmodjo (2008:45) tolak ukur terpenting kinerja perusahaan adalah EPS (Earning Per Share atau laba per saham). Jika nilai EPS ini terus meningkat, berarti kinerja perusahaan semakin membaik.

Penelitian sebelumnya yang dilakukan oleh Giovanni Budiman (2013) dan Ary Kurniawan (2011) yang menyatakan bahwa EPS memiliki pengaruh positif terhadap return saham. Sedangkan penelitian yang dilakukan oleh Desy Arista (2012) dan Abdul Karim (2015) menyatakan bahwa EPS memiliki pengaruh negatif terhadap return saham.

Berdasarkan uraian tersebut, maka dapat dirumuskan hipotesis sebagai berikut.

$\mathrm{H}_{3}$ : Earning Per Share (EPS) berpengaruh positif terhadap Return Saham

Price Earning Ratio terhadap Return Saham.

Menurut Brigham dan Houston (2010:150) price earning menunjukkan jumlah yang rela dibayarkan oleh investor untuk setiap dolar laba yang dilaporkan.
Menurut Wira (2014: 77) PER menggambarkan berapa banyak investor berani menghargai saham itu. Menurut Fahmi (2012:289) bagi para investor semakin tinggi Price Earning Ratio maka pertumbuhan laba yang diharapkan juga akan mengalami kenaikan

Penelitian sebelumnya yang dilakukan oleh Najmiyah, Edy Sujana dan Ni Kadek Sinarwati (2014) dan Putu Rendi Suryagung Ryandi, I Ketut Sujana (2014) menyatakan bahwa PER berpengaruh positif terhadap harga saham. Sedangkan yang dilakukan oleh Meythi (2012) menyatakan bahwa PER memiliki pengaruh negatif terhadap return saham.

Berdasarkan uraian tersebut, maka dapat dirumuskan hipotesis sebagai berikut.

$\mathrm{H}_{4}$ : Price Earning Ratio (PER) berpengaruh positif terhadap Return Saham

\section{Price to Book Value terhadap Return Saham.}

According to Brownlee, Ferris and Haskins (2001:603) One of the most widely used indicators of a company's investment potential is the price earnings $(P / E)$ and book value, because the market price of a share of stock is function of investors' perceptions regarding a company's potential, the same factors that affect those perceptions also affect the P/E Ratio and Book Value-such as the company's relative risk, earnings history, and growth potential. A final popular index is the book value per share.

Penelitian sebelumnya yang dilakukan oleh Edhi Asmirantho (2014), Desy Arista (2012), Ary Kurniawan (2011), Tri Laksita Asmi (2014), Dwi Martanti, Mulyono, Rahfiani Khairurzka (2009), dan Putu Rendi Suryagung 
Ryandi, I Ketut Sujana (2014) yang menyebutkan bahwa PBV berpengaruh positif terhadap return saham. Sedangkan penelitian yang dilakukan oleh Najmiyah , Edi Sujana, Ni Kadek Sinarwati (2014) menyatakan bahwa PBV berpengaruh negatif terhadap return saham.

Berdasarkan uraian tersebut, maka dapat dirumuskan hipotesis sebagai berikut.

$\mathrm{H}_{5}$ : Price to Book Value (PBV) berpengaruh positif terhadap Return Saham

\section{Rasio Solvabilitas, Rasio Profitabilitas, Rasio Nilai Pasar}

Menurut Murti (2011:65) menyatakan bahwa keuntungan (return) pada saham terdiri dari dua komponen yaitu dividend yield dan capital gain (loss). Capital gain merupakan keuntungan yang didapat dari selisih harga beli dan harga jual. Sedangkan dividend yield adalah pembagian keuntungan yang diberikan perusahaan penerbit saham tersebut atas keuntungan yang dihasilkan perusahaan. Mengingat tidak selamanya perusahaan membagikan dividend kepada para pemegang saham, maka dapat diperoleh dari capital gain.

Berdasarkan uraian tersebut, maka dapat dirumuskan hipotesis sebagai berikut.

\section{H6 : Rasio Solvabilitas (Long Term Debt to Equit Ratio), Rasio Profitabilitas (Return On Equity), dan Rasio Nilai Pasar (Earning Per Share, Price Earning Ratio, Price to Book Value) secara bersama-sama berpengaruh terhadap Return Saham.}

\section{Metodologi Penelitian}

Penelitian ini menggunakan jenis penelitian varifikatif dengan metode explanatory survey, untuk mengetahui pengaruh antara variabel independen dengan variabel dependen. Teknik penelitian yang digunakan adalah statistik inferensial.

Metode penarikan sampel yang digunakan adalah purposive sampling (sampel yang memenuhi kriteria yang sesuai dengan masalah yang diteliti). Metode pengumpulan data yang digunakan adalah metode studi pustaka dan metode dokumentasi.

Metode analisis data yang digunakan adalah uji asumsi klasik, yang terdiri dari uji normalitas, uji heteroskedastisitas, uji multikolinearitas, dan uji autokorelasi. Selain itu, analisis regresi linier berganda, uji t, dan uji $\mathrm{F}$.

\section{Hasil dan Pembahasan}


Tabel 1

Analisis Satistik Deskriptif

Descriptive Statistics

\begin{tabular}{|c|r|r|r|r|r|}
\hline & $\mathrm{N}$ & Minimum & Maximum & \multicolumn{1}{c|}{ Mean } & Std. Deviation \\
\hline RETURN & 33 & -92.00 & 248.00 & 5.7576 & 61.57517 \\
LTDR & 33 & .02 & 1.16 & .3027 & .32039 \\
ROE & 33 & -2.92 & 25.32 & 8.9636 & 7.06587 \\
EPS & 33 & -194.38 & 1574.09 & 332.4897 & 405.12378 \\
PER & 33 & -46.05 & 607.12 & 45.0788 & 117.72184 \\
PBV & 33 & .32 & 3.43 & 1.2870 & .77890 \\
Valid N & 33 & & & & \\
(listwise) & & & & & \\
\hline
\end{tabular}

(Sumber : Data diproses dengan SPSS versi 20)

Hasil analisis statistik deskriptif pada tabel 1 dapat diketahui bahwa Return Saham memiliki nilai minimum 92,00, nilai maximum sebesar 248,00. Return Saham memiliki nilai rata-rata sebesar 5.7576 dengan standar deviasi sebesar 61,57517. Nilai standar deviasi yang lebih tinggi dari nilai rata-rata hitungnya menunjukkan bahwa Return Saham memiliki data yang bervariasi (naik turun) dengan cukup tinggi. Data Long Term Debt to Equity Ratio (LTDR) memiliki minimum 0,02 , nilai maximum sebesar 1,16. Long Term Debt to Equity Ratio (LTDR) memiliki nilai rata-rata sebesar 0,3027 dengan standar deviasi sebesar 0,32039. Nilai standar deviasi yang lebih tinggi dari nilai rata-rata hitungnya (mean) menunjukkan bahwa Long Term Debt to Equity Ratio (LTDR) memiliki data yang bervariasi (naik turun) yang cukup tinggi. Data Return On Equity (ROE) memiliki nilai minimum 2,29, nilai maximum sebesar 25,32. Return on Equity (ROE) memiliki nilai rata-rata sebesar 8,9636 dengan standar deviasi sebesar 7,06587. Nilai standar deviasi yang lebih kecil dari nilai rata-rata hitungnya (mean) menunjukkan bahwa Return On Equity (ROE) memiliki variasi data yang rendah. Data Earning Per Share (EPS) memiliki nilai minimum 194,38, nilai maximum 1574,09. Earning Per Share (EPS) memiliki nilai rata-rata sebesar 332,4897 dengan standar deviasi sebesar 405,12378. Nilai standar deviasi yang lebih tinggi dari nilai rata-rata hitungnya (mean) menunjukkan bahwa Earning Per Share (EPS) memiliki data yang bervariasi (naik turun) yang cukup tinggi. Data Price Earning Ratio (PER) memiliki nilai minimum -46,05, nilai maximum 607,12. Price Earning Ratio (PER) memiliki nilai rata-rata sebesar 45,0788 dengan standar deviasi sebesar 117,72182. Nilai standar deviasi yang lebih tinggi dari nilai rata-rata hitungnya (mean) menunjukkan bahwa Earning Per Share (EPS) memiliki data yang bervariasi (naik turun) yang cukup tinggi. Data Price to Book Value (PBV) memiliki nilai minimum 0,32 , nilai maximum sebesar 3,43. Price to Book Value (PBV) memiliki nilai rata-rata sebesar 1,2870 dengan standar deviasi sebesar 0,77890. Nilai standar deviasi 
yang lebih kecil dari nilai rata-rata hitungnya (mean) menunjukkan bahwa Price to Book Value (PBV)memiliki variasi data yang rendah.

\section{Pengujian Asumsi Klasik}

Uji normalitas dengan one sample kolmogorov smirnov menunjukkan nilai signifikansi (Asymp. Sig. 2-tailed) adalah sebesar 0,137 lebih besar dari 0,05 (0,760 $>$ 0,05). Sehingga dapat disimpulkan bahwa nilai residual yang dihasilkan dari model regresi terdistribusi dengan normal. Uji multikolinearitas untuk seluruh variabel independen menunjukkan nilai tolerance di atas 0,1 $(>0,1)$ dan nilai VIF di bawah $10(<10)$ sehingga dapat dikatakan bahwa tidak ada masalah multikolinearitas antar variabel independen pada model regresi. Uji heteroskedastisitas dengan uji glejser menunjukkan bahwa seluruh variabel independen memiliki nilai signifikansi di atas $0,1(>0,1)$ sehingga dapat dikatakan bahwa model regresi bebas dari heteroskedastisitas. Uji autokorelasi dengan uji run test menunjukkan nilai Asymp. Sig. (2-tailed) adalah sebesar 0,286 lebi besar dari $0,05(0,286>0,05)$. Sehingga dapat disimpulkan bahwa model regresi terbebas dari masalah autokorelasi.

Tabel 2

Uji Model Regresi Linier Berganda Model Summary ${ }^{b, c}$

\begin{tabular}{|l|r|r|r|r|}
\hline Model & \multicolumn{1}{|c|}{$\mathrm{R}$} & R Square & $\begin{array}{c}\text { Adjusted R } \\
\text { Square }\end{array}$ & $\begin{array}{c}\text { Std. Error of } \\
\text { the Estimate }\end{array}$ \\
\hline 1 & $.923^{\mathrm{a}}$ & .852 & .825 & 1.00449 \\
\hline
\end{tabular}

a. Predictors: (Constant), PBV, PER, LTDR, EPS, ROE

b. Dependent Variable: RETURN

(Sumber : Data diproses dengan SPSS versi 20)

Berdasarkan tabel 2 dapat diketahui bahwa Nilai korelasi berganda (R) sebesar 0,923, artinya korelasi (hubungan) antara variabel Long Term Debt to Equity Ratio, Return On Equity, Earning Per Share, Price Earning Ratio, Price to Book Value terhadap variabel Return Saham adalah sebesar 0,923 atau 92,3\%.

Nilai koefisien determinasi $\left(\mathrm{R}^{2}\right)$ adalah sebesar 0,852. Menunjukkan bahwa variasi dari Return Saham dapat diterangkan oleh LTDR, ROE, EPS, PER, dan PBV sebesar 0,852 atau $85,2 \%$, sedangkan sisanya sebesar $14,8 \%$
(100\%-85,2\%) diterangkan oleh variabel lain yang tidak termasuk dalam model ini.

Nilai Adjusted $R$ Square adalah sebesar 0,825. Hasil ini menunjukkan bahwa sumbangan pengaruh variabel independen (LTDR, ROE, EPS, PER, dan PBV) terhadap varaibel dependen (Return Saham) adalah sebesar 0,825 atau 52,5\%, sedangkan sisanya sebesar $17,5 \%$ dipengaruhi oleh variabel independen lain. Adjusted $R$ Square digunakan dalam penelitian yang menggunakan lebih dari satu variabel independen. 
Standar Error of the Estimate adalah ukuran kesalahan prediksi dalam penelitian ini yaitu sebesar 1,00449 atau $100,449 \%$, artinya kesalahan yang dapat terjadi dalam memprediksi tingkat Return Saham sebesar 100,449\%.

Tabel 3

Hasil Uji t

Coefficients $^{\mathrm{a}, \mathrm{b}}$

\begin{tabular}{|r|r|r|r|r|r|}
\hline \multirow{2}{*}{ Model } & \multicolumn{2}{|c|}{$\begin{array}{c}\text { Unstandardized } \\
\text { Coefficients }\end{array}$} & \multicolumn{1}{c|}{$\begin{array}{c}\text { Standardized } \\
\text { Coefficients }\end{array}$} & \multicolumn{1}{c|}{ Sig. } \\
\cline { 2 - 4 } & \multicolumn{1}{|c|}{ B } & Std. Error & \multicolumn{1}{c|}{ Beta } & & \\
\hline \multirow{2}{*}{ (Constant) } & 20.483 & 5.320 & & 3.850 & .001 \\
LTDR & -31.219 & 4.071 & -.650 & -7.669 & .000 \\
ROE & -1.503 & .273 & -.660 & -5.510 & .000 \\
EPS & .033 & .007 & .481 & 5.061 & .000 \\
PER & -.039 & .029 & -.106 & -1.372 & .181 \\
PBV & -.646 & 3.166 & -.022 & -.204 & .840 \\
\hline
\end{tabular}

a. Dependent Variable: RETURN

(Sumber: Data diproses dengan SPSS versi 20)

Berdasarkan output tabel 3 dapat dibentuk persamaan regresi linier berganda sebagai berikut.

$$
\begin{gathered}
\text { Return Saham = } 11,301-4,831(\mathrm{LTDR})- \\
0,157(\mathrm{ROE}) \\
0,002(\mathrm{EPS}) \\
+0,019(\mathrm{PER})- \\
\\
1,209(\mathrm{PBV})
\end{gathered}
$$

Berdasarkan tabel 3 hasil uji $\mathrm{t}$ di atas dapat dilihat, sebagai berikut.

a) Long Term Debt to Equity Ratio terhadap Return Saham

-t hitung $\leq$-t tabel $(-7,669 \leq-2,05183)$ dengan tingkat signifikansi di bawah 0,05 , yaitu 0,000 maka dapat disimpulkan bahwa Long Term Debt to Equity Ratio (LTDR) berpengaruh negatif signifikan terhadap Return Saham.

b) Return On Equity terhadap Return Saham

$-\mathrm{t}$ hitung $<\mathrm{t}$ tabel $(-5,510<2,05183)$ dengan tingkat signifikansi di bawah 0,05 yaitu 0,000 maka dapat disimpulkan bahwa Return On Equity (ROE) tidak berpengaruh terhadap Return Saham. Namun berdasarkan hasil Beta menunjukkan bahwa arah hubungan antara Return On Equity dengan Return Saham adalah negatif signifikan. 
c) Earning Per Share terhadap Return Saham

$\mathrm{t}$ hitung $\geq \mathrm{t}$ tabel $(5,061 \geq 2,05183)$ dengan tingkat signifikansi di bawah 0,05 yaitu 0,000 maka dapat disimpulkan bahwa Earning Per Share (EPS) berpengaruh positif signifikan terhdap Return Saham.

\section{d) Price Earning Ratio terhadap} Return Saham

-t hitung $<\mathrm{t}$ tabel $(-1,372<2,05183)$ dengan tingkat signifikansi di atas 0,05 yaitu 0,181 maka dapat disimpulkan bahwa Price Earning Ratio (PER) tidak berpengaruh terhadap Return Saham. Namun berdasarkan hasil Beta menunjukkan bahwa arah hubungan antara Price Earning Ratio (PER) dengan Return Saham adalah negatif tidak signifikan.

e) Price to Book Value terhadap Return Saham

$-\mathrm{t}$ hitung $<\mathrm{t}$ tabel $(-0,2014<$ 2,05183) dengan tingkat signifikansi di atas 0,05 yaitu 0,840 maka dapat disimpulkan bahwa Price to Book Value (PBV) tidak berpengaruh terhadap Return Saham. Namun berdasarkan hasil Beta menunjukkan bahwa arah hubungan antara Price to Book Value (PBV) dengan Return Saham adalah negatif tidak signifikan.

Tabel 4

Hasil Uji F

ANOVA $^{\text {a,b }}$

\begin{tabular}{|l|r|r|r|r|r|}
\hline \multirow{2}{*}{ Model } & \multicolumn{1}{c|}{$\begin{array}{c}\text { Sum of } \\
\text { Squares }\end{array}$} & Df & Mean Square & F & Sig. \\
\hline \multirow{2}{*}{1 Regression } & 157.204 & 5 & 31.441 & 31.160 & $.000^{c}$ \\
Residual & 27.243 & 27 & 1.009 & & \\
\hline & 184.447 & 32 & & & \\
\hline
\end{tabular}

a. Dependent Variable: RETURN

b. Predictors: (Constant), PBV, PER, LTDR, EPS, ROE

(Sumber : Data diproses dengan SPSS versi 20)

Dapat dilihat F hitung > F tabel $(31,160>$ 2,73). Begitupun berdasarkan tingkat signifikansi, dari hasil uji $\mathrm{F}$ berdasarkan tabel 4 dapat dilihat bahwa tingkat signifikansinya $<0,05$, yaitu 0,000. Jadi dapat disimpulkan bahwa kinerja keuangan (Long Term Debt to Equity Ratio, Return On Equity, Earning Per Share, Price Earning Ratio, dan Price Book Value) secara bersama-sama berpengaruh terhadap Return Saham.

\section{Penutup}

Sumbangan pengaruh variabel independen Long Term Debt to Equity Ratio (LTDR), Return On Equity (ROE), Earning Per Share (EPS), Price Earning Ratio (PER), dan Price to Book Value (PBV) terhadap varibel dependen yaitu Return Saham adalah sebesar 0,825 atau $82,5 \%$, sedangkan sisanya $17,5 \%(100 \%$ $82,5 \%$ ) dipengaruhi oleh variabel independen lain.

Hasil analisis secara parsial Long Term Debt to Equity Ratio berpengaruh negatif terhadap Return Saham pada

JIMFE (Jurnal Ilmiah Manajemen Fakultas Ekonomi)

Volume 2 No. 1 Tahun 2016 Edisi 2, Hal. 41-52 
perusahaan sub sektor otomotif yang terdaftar di BEI periode 2012-2014.

Hasil analisis secara parsial Return On Equity tidak berpengaruh terhadap Return Saham pada perusahaan sub sektor otomotif yang terdaftar di BEI periode 2012-2014. Nilai Beta menujukkan arah hubungan Return On Equity terhadap Return Saham adalah negatif signifikan.

Hasil analisis secara parsial Earning Per Share berpengaruh positif terhadap Return Saham pada perusahaan sub sektor otomotif yang terdaftar di BEI periode 2012-2014.

Hasil analisis secara parsial Price Earning Ratio tidak berpengaruh terhadap Return Saham pada perusahaan sub sektor otomotif yang terdaftar di BEI periode 2012-2014. Nilai Beta menujukkan arah hubungan Price Earning Ratio terhadap Return Saham adalah negatif tidak signifikan.

Hasil analisis secara parsial Price to Book Value tidak berpengaruh terhadap Return Saham pada perusahaan sub sektor otomotif yang terdaftar di BEI periode 2012-2014. Nilai Beta menunjukkan arah hubungan Price to Book Value terhadap Return Saham adalah negatif tidak signifikan.

Berdasarkan uji secara simultan (bersama-sama) menunjukkan bahwa Long Term Debt to Equity Ratio, Return On Equity, Earning Per Share, Price Earning Ratio, Price to Book Value berpengaruh signifikan terhadap Return Saham.

\section{DAFTAR PUSTAKA}

Abdul Karim. 2015. Analisis Pengaruh Faktor Internal dan Eksternal Terhadap Return Saham Perusahaan Manufaktur yang terdaftar di Bursa Efek Indonesia Periode 2010-2012.
Media Ekonomi dan Manajemen Vol.30 No.1 (2015) ISSN: 08541442

Ari Anggraini Winadi Prasetyoning Tyas. 2010. Pengaruh Rasio Likuiditas, Aktivitas, Profitabilitas, Leverage, dan economic value added terhadap return saham. Jurnal of Economic Vol.1 No.2.

Ary Kurniawan. 2011. Pengaruh Kinerja

Keuangan terhadap Return Saham pada perusahaan manufaktur yang terdaftar di Bursa Efek Indonesia periode 2008-2010. Jurnal Informasi Perpajakan, Akuntansi dan Keuangan Publik. Vol.6 No.2 (Juli 2012)

Brealey Richard A, Stewart C Myers \& Allen Franklin. 2014. Principle of Corporate Finance. Mc Graw Hill, New York.

Brigham, Eugene F \& Houston, Joel F Houston.2006. Fundamentals of Financial Management (Dasardasar Manajemen Keuangan), Alihbahasa Ali Akbar Yulianto. Salemba Empat, Jakarta.

Brigham, Eugene F \& Houston, Joel F Houston. 2010. Dasar-dasar Manajemen Keuangan. Salemba Empat, Jakarta.

Desmond Wira. 2014. Analisis Fundamental Saham, Edisi ke-2. Exceed, Jakarta.

Desy Arista. 2012. Analisis Faktorfaktor yang Mempengaruhi Return Saham. Jurnal Ilmu Manajemen dan Akuntansi Terapan. Vol.3 No.1.

Dwi Martanti, Mulyono, Rahfiani Khairurzka. 2009. The effect of financial ratios, firm size, and cash flow from operating activities in the interim report to 
the stock return. Chinese Business Review, ISSN 15371506, USA. Journal Vol.8 No.6.

Edhi Asmirantho. 2014. Effect of Financial Fundamental Factors and Macroeconomics To Stock Return With Implications On corporate value (tobins Q)Real Estate and Property goPublic in Indonesia. Fakultas Ekonomi Doktor Ilmu Manajemen, JOBMAN Vol. 1 No. 1, Januari 2014.

Giovanni Budialim. 2013. Pengaruh Kinerja Keuangan dan Risik oTerhadap Return Saham Perusahaan Sektor Consumer Goods Di Bursa Efek Indonesia Periode 2007-2011. Jurnal Ilmiah Mahasiswa Universitas Surabaya.Vol.2., No 1.

Hasrul Siregar dan Fatimah. 2013. Analisis Pengaruh Fundamental Terhadap Return Saham Perbankan. Jurnal Manajemen STIE IBBI Vol.19 No.1 (2013)

Komala, Lieviea, Angela Pinkan dan Paskah Ika Nugroho. The Effect of Probability Ratio, Liquidity, and Debt towards Invesment Return. Journal of Business and Economic, 2013. Vol.4, No.11, PP.1176-1186.

Meythi, Mariana Mathilda. 2012. Pengaruh Price Earning Ratio dan Price Book Value terhadap return saham. Jurnal Akuntansi, Volume 4, Nomor 1.

Najmiyah, Edy Sujana dan Ni Kadek Sinarwati.2014. Pengaruh Price Book Value (PBV), Price Earning Ratio (PER), dan Debt to Equity Ratio (DER) terhadap Return Saham pada Industri Real Estate dan Property yang terdaftar di Bursa Efek Indonesia Periode 2009-2013. Ejournal S1 Ak.Universitas Pendidikan Ganesha Jurusan Akuntansi Program S1 Vol.2 No.1.

Okky Safitri, Sinarwati dan Anantawikrama Tungga Atmaja. 2015. Analisi Pengaruh Profitabilitas, Likuiditas dan Leverage Terhadap Return Saham pada perusahaan Manufaktur yang terdaftar di BEI. E-journal S1 Ak.Universitas Pendidikan Ganesha Jurusan Akuntansi Program S1 Vol.3 No.1.

Philippatos, George C \& William W. Sihler (1991), Financial Management text and cases, Second editions, by Allyn\& Bacon A division of Simon \& Schuster. Inc, United States of America.

Putu Rendi Suryagung Ryandi, I Ketut Sujana. 2014. Pengaruh Price Earning Ratio, Profitabilitas, dan Nilai Perusahaan terhadap Return Saham. ISSN: 2302-8556. E-Jurnal Akuntansi Universitas Udayana 8.2 (2014): 202-216.

Richard Brownlee E, Kenneth R, Ferris, and Mark E, Haskins, 2001, Corporate Financial Reporting, McGraw-Hill/Irwin Companies,Inc United States.

Robert. Ang, 1997. Buku Pintar Pasar Modal Indonesia. Mediasoft Indonesia. Jakarta.

Sanjay K. Pandey. 2008. The Role of Organization in Fostering Public Service Motivation. DP, Moynihan. Washington.

Sonja Yvonne Momuat. 2005. Analisis Pengaruh Net Profit Margin, Long Term Debt to Equity dan 
Inventory Turover terhadap return saham. Tesis Program Studi Magister Manjemen Program Pasca Sarjana Universitas Diponegoro Semarang.

Tri Laksita Asmi. 2014. Current Ratio, Debt to Equity Ratio, Total Asset Turnover, Return on Asset, Price to Book Value Sebagai Faktor Penentu Return Saham.
Management Analysis Journal Vol.3 No.2.

Wahyu Murti. 2011. Pengaruh Kinerja Keuangan terhadap Return Saham. Cetakan Pertama. Cintya Press.

Van Horne, James C \&Wachowicz, John M. Fundamentals Of Financial Management. 1998. Prentice Hall International, Inc.

www.korantempo.com 